\title{
Book Review of Sugata Bose, the Nation as Mother and Other Visions of Nationhood, India: Penguin Random House, 2017
}

\author{
JYOTI ATWAL \\ Centre for Historical Studies, School of Social Sciences, \\ Jawaharlal Nehru University, New Delhi, India.

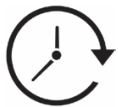 \\ Article History
}

Published on: 10 December 2019

Sugata Bose's latest book is primarily focused on nation, reason and religion in the Indian political thought and practice from the late $19^{\text {th }}$ century to the present. The book contains ten inter referential essays/lectures which were delivered between 1997 and 2017. Second part of the book carries Bose's six speeches in the Lok Sabha between 2014 and 2017.

The first essay entitled 'The Nation as Mother' is a close scrutiny of the late $19^{\text {th }}$ century intellectual exercise in Bengal through which the nation and the Mother came to be intricately tied up in various creative political discourses. Their reason and patriotism often incorporated an artistic and a magical vision of the Mother. Bankim's Bande Mataram and 1905 evocation of Bharatmata by Abanindranath Tagore had its denouement in the myth of Parashuram performing matricide (symbolised by 1947 partition and 1990 Ayodhaya event).

Bose reiterates that despite the liberal reception of the concept of Bharatmata/Mother Bengal by some Bengali Muslim nationalists, the 'equation of nation with goddess understandably left many Muslims cold' ( p15). However, Mother India could always be tailored to suit a political context. In 1937 the Bande Mataram controversy led Tagore to suggest that evocation of Durga in Bankim's song be left out.

The rest of the chapters form a sudden break from the discussion on variegated imaginations of Mother India. In the second chapter entitled 'Nation, Reason and Religion: India's Independence in International

\footnotetext{
CONTACT Jyoti Atwal $\$ jyotiatjnu@gmail.com $\boldsymbol{Q}$ Centre for Historical Studies, School of Social Sciences, Jawaharlal Nehru University, New Delhi, India.
}

\section{(c) (i)}


Perspective', Bose draws distinction between religious sensibility and religious bigotry. He argues that religious sensibility could in the late $19^{\text {th }}$ century be perfectly compatible with a rational frame of mind and that colonised intellectuals sought alternative sources of escape from the oppressive present (p40). It is interesting to note here that K.N.Pannikar in 1990s had explored the class dimension of the complex $19^{\text {th }}$ century colonised intellectual Hindus. In another chapter on 'Different Universalisms and Colourful Cosmopolitanisms', Bose asserts that a universalized patriotism emerged at various venues across the colonised world (including Africa) where the binary of secular and religious was non identifiable ( $p 110)$. Through different chapters, Bose interestingly strikes a comparison between the two nationalisms - Irish and Indian. He underlines the failure of the British to resolve the religious question. Both nations ultimately experienced partition. Another important question which Bose poses is : was hyper rationalism (opposition between reason and emotion) characteristic of modernity under colonial rule? The success of Gandhi lay in creating fusion of love for a territorial homeland with the extraterritorial loyalty of religion. The classic 'moment of manoeuvre' was initiated by the Gandhian endorsement of the cause of Khilafat. But Bose is mindful of Gandhi's succumbing to Hindu majoritarianism towards the 1940s. The underlying argument by Bose is that through the history of anti colonialism and 'religion as faith within the limits of morality' did not prove detrimental to the cause of national unity.

The next essay on 'Instruments and Idioms of Colonial and National Development : India's Historical and Comparative Perspective' explores India's post colonial economy. Bose engages with David Ludden's formulation that pre colonial culture produced multiple, overlapping levels and arenas of authority more than centralised states (p80).

Bose argues that economic reforms pushed by Congress government in 1990s did not address the need for expanding social opportunities. There is a need for creation of decentred democracy and to come out with alternative democratic models of state.

In the next essay on 'The Spirit and Form of Ethical Polity: A Meditation on Aurobindo's Thought' discusses the rootedness of Indian anti colonialism, which was nourished by many regional patriotisms, competing visions of nationalism and extra territorial affinities of religiously informed universalisms (p86). Bose highlights the misappropriation of Aurobindo by the Hindu right. Aurobindo had been an iconic hero of the Swadeshi movement in Bengal but Bose argues that the invocation to sanatan dharma by Aurobindo is deeply troubling to a secularist historian like Sumit Sarkar. Secularists, according to the author, have therefore been responsible for such abandonment of the domain of religion to the religious bigots.

In another essay Bose highlights the main events leading to the partition of India. He formulates that Gandhi's relevance to the Congress as a leader of mass movements diminished as soon as soon as the departure of the British became obvious. Gandhi was aware that the Muslims had not been amused by his civil disobedience and Quit India movements. The challenge of transition of power and violence around it has been discussed by Bose from different perspectives - most significantly the gender.

In one of the speeches in the Parliament in 2016, the author rearticulates that he would have liked a discussion with Kanhaiya (JNUSU president) on the subject of history. The communists had participated in the national freedom struggle but also betrayed the freedom struggle at crucial moments during the 1942 movement and during Azad Hind movement led by Netaji Subhas Chandra Bose.

Overall these rich essays have been brought together with the speeches to explore both the oppressive and the liberating aspects of nationalism. One wishes that the exploration of Mother India had continued beyond the first essay and included challenging questions posed by the prevalence of child marriage and rape in contemporary India. The nationalist imagination was further fuelled by the text called Mother India (Katherine Mayo, 1927), particularly in the period between 1930s and 1950s. This book was a drain 
inspector's report highlighting child marriage and the 'slave' mentality of the Indians. It partly resolved the colonial ambivalence by creating a pan Indian anti colonial mood. Feminist scholarship has made this text a point of reference to mark a shift in gender and nation politics in colonial and post colonial India. ${ }^{1}$

I have pointed out to the cinematic imagination of Mother India ${ }^{2}$ in 1957 movie by Mehboob Khan. In the movie a poor peasant woman has been enabled take on the role of Mother India, which carries sedimented layers of politico-cultural meanings.

Bose could have included some non Bengali intellectuals/writers as well. Noticeable are Bhartendu Harishchandra's plays and essays in the 1870s. He is well known for his satirical plays like 'Andher Nagri' and 'Bharat Durdhasha'. 